\title{
Mechanical and electrical properties of the solid sapropel
}

\author{
Andris Martinovs ${ }^{1}$, Josef Timmerberg ${ }^{2}$, Rasma Tretjakova ${ }^{1}$, Paul Beckmann ${ }^{2}$, \\ Valentina Popa ${ }^{1}$, Regina Wagner ${ }^{2}$ \\ ${ }^{1}$ Rēzeknes Augstskola, Faculty of Engineering, \\ Address: Atbrīvošanas aleja 115/K-4, Rèzekne, LV-4601, Latvia \\ ${ }^{2}$ Jade University of Applied Sciences, \\ Address: Friedrich-Paffrath-Str. 101, 26389, Wilhelmshaven, Germany
}

\begin{abstract}
In this paper are explored the mechanical (ultimate compression strength, ultimate strain, Young's modulus, hardness) and the electrical (relative permittivity, specific electrical resistance, quality factor, their dependence on the electric field frequency in the range till $1 \mathrm{MHz}$ ) properties of the solid sapropel. For the researches are used samples from the solid, monolith sapropel (obtained in the drying process) and samples from the sapropel powder that are pressed with a different force; before the measurements, a part of these samples were heated. There is explored the dependence of the relative permittivity on temperature. Are explored the methods for the forming of the products from the solid sapropel powder.
\end{abstract}

Keywords: solid sapropel, mechanical properties, electrical properties, sapropel powder.

\section{INTRODUCTION}

Sapropel is a product of mechanical, physical, chemical, and biological transformations of the remnants of lacustrine plants and animals, as well as inorganic components of biogenic origin [1]. Process of creation of sapropel is reflected in works of many authors, for example [2], [3], [4], [5]. Sapropel is renewable natural resource. Overall resources of sapropel in Latvia are approximately 2 billion $\mathrm{m}^{3}$; layer of sapropel in hollows of lakes collects with speed 1-2mm per year; sapropel is used in agriculture, gardening, forest husbandry, animal husbandry, chemical industry, building, balneology and cosmetology; the amount of resources of sapropel and wide possibilities of using make it a national-scale strategic natural resource [5]. Lake sapropel production methods are reviewed in article [6]. In industrial scale in Latvia sapropel is used for production of soil enrichers by mixing it with peat. In small amounts it is used as a binder in building [7]. It is possible to use sapropel as modifying additive for binders in production of brown coal briquettes; dry lacustrine sapropel accelerate the oxidation processes and enhance adhesive coupling in the coal-binder system [1]. Admixing of sapropel enhance mechanical strength of brown coal briquettes; discovered increasing of adhesion strength of compounds of coal grains and goudron by using sapropel as modifying additive [8]. Sapropel from which free water is separated is possible to use as natural sorbent [1]. In sapropel approximately $75 \%$ is organic matter; it determines biological activity, biochemical resistance, and adhesiveness of sapropel [1], [9]. According to [5] composition of organic matters in sapropel is $15-85 \%$; composition and properties of various sapropel deposits are very different. Drugs derived out of sapropel can be used in veterinary medicine [10] as biostimulants [11] and as biologically active substances [12]. Sapropel is a good adsorbent; capacity for short residues is $70-75 \%$ [1]. Biological and chemical composition of sapropel layers in different depths can be used as biomarker, which gives information about changes of earth climate and geological conditions [13], [14]. Outlook would be using of this resource also in other national economy sectors so that brings maximally high added value. When the sapropel dries, it converts to a solid substance that is similar to stone. The solid sapropel at present it is a new, in national economy almost unused material. It is necessary to know the mechanical, physical (thermal, electrical etc.), chemical and biological properties to find the maximal effective use of the solid sapropel. Researches of chemical properties of the sapropel were made by many authors, for example [4], [15], [16], [17]. Proved that the sapropel extracts have antibacterial properties and defined a positive correlation between the chemical composition and the biological activity

ISSN 1691-5402 
of the sapropel [18]. A wide review of works of many authors about the classification, formation, chemical and biological properties see in [5]. The magnetic properties of the sapropel were researched in [19]. The thermal properties of the Black sea sapropel were researched in [20]; determined that depending on humidity $(25-72 \%)$ thermal conductivity is in the range $0.65-1.25 \mathrm{~W} /(\mathrm{m} \cdot \mathrm{K})$, specific heat capacity is $1580-3260 \mathrm{~J} /(\mathrm{kg} \cdot \mathrm{K})$, density is $1150-1900 \mathrm{~kg} / \mathrm{m}^{3}$. At the same time mechanical and electrical properties of the solid sapropel are less researched.

The aim of the work is to explore mechanical (ultimate compression strength, ultimate strain, Young's modulus, hardness) and electrical (relative permittivity, specific electrical resistance, quality factor) properties of the solid sapropel so that it would be possible to find the most effective further use of this material.

\section{MATERIALS AND METHODS}

For this research is used a sapropel that was gotten in Latvia, Rēzekne region, in the lake Ubogova (from depth) and in the Diunokla bay of the lake Rušons (from the upper layer, $0.3-0.5 \mathrm{~m}$ deep). The sapropel that was gathered before 1-3 months is filled into moulds and dried in the laboratory conditions (temperature $19-21^{\circ} \mathrm{C}$, relative humidity $50-60 \%$ ). To test the mechanical properties, are used cubic, monolith samples of the solid sapropel with polished surfaces and a dimension $11 \times 11 \times 11 \mathrm{~mm}$. For the testing electrical properties are used parallelepipedform, monolith samples of the solid sapropel with polished surfaces and a dimension $11 \times 11 \times 4 \mathrm{~mm}$. The solid rest in the sapropel makes up about $8 \%$. During the process of drying, there are several serious problems to form the samples of the solid sapropel when this material become dry, it shrinks hard, cracks, crinkles, loses its form, consequently there are a lot of defective samples. So there is also used one another method to prepare the samples: particles of the solid sapropel are grinded into powder; this powder is to fill into cylindrical forming die (diameter $20 \mathrm{~mm}$ ) and to press with a constant force $(3,5,8,10,15$ tons); as a result we become cylindrical samples with a diameter $19.3 \mathrm{~mm}$, height about $21 \mathrm{~mm}$ (to test the mechanical properties) and $5 \mathrm{~mm}$ (to test the electrical properties). The size of the sapropel-powder-particles is not measured in the experiments.

To test the electrical properties is to apply silverlacquer (Kemo N36BA L100 Electronic Conducting Silver) electrodes on two opposite sample-faces (with the largest surface area), with a thickness about $0.05 \mathrm{~mm}$.

There is performed a compression test for the samples with the universal tensile machine Zwick/ Roell Z-150; compression rate $-10 \mathrm{~mm} / \mathrm{min}$; temperature $20^{\circ} \mathrm{C}$. Using the compression curves, we can determine the ultimate compressive strength, strain and Young's modulus of the investigated material.

The electrical capacity of the samples for the DC case is determined with the Fluke 189 True RMS Multimeter. A sample of the solid sapropel (with a silver layer on the opposite faces) is inserted into a holder between steel electrodes that are connected with the multimeter. Then is measured the capacity $\mathrm{C}$ of the steel electrodes, among whom is placed the sapropel. After it, the sample of the sapropel is ejected from the holder; distance between the steel electrodes is equal with a thickness of the sample. Subsequently is measured the capacity $\mathrm{C}_{0}$ of the steel electrodes, among whom is air. If are given geometrical sizes of the samples- area of the silver electrode A, thickness of the sapropel-layer $\mathrm{d}$, then the relative permittivity is:

$$
\varepsilon=\frac{\left(C-C_{0}\right) \cdot d}{\varepsilon_{0} \cdot A},
$$

where $\varepsilon_{0}=8.85 \cdot 10-12 \mathrm{~F} / \mathrm{m}$ - electric constant.

The electrical resistance $\mathrm{R}$ of the samples for the DC case is determined with the Megohmmetre Sefelec M1500P. The specific electrical resistance:

$$
\rho=\frac{R \cdot A}{d} .
$$

For the test of the electrical properties in the range from $20 \mathrm{~Hz}$ to $1 \mathrm{MHz}$ is used the HP 4284A Precision LCR Meter; there is measured the conductance $G$ and the susceptance B of the inspected samples. To calculate the relative permittivity and the specific electrical resistance are used equations (1), (2),

$$
R=\frac{1}{G}
$$

and

$$
C=\frac{B}{2 \cdot \pi \cdot f},
$$

where f- frequency of the electric field.

The quality factor $\mathrm{Q}$ (that is inverse proportional to the dissipation factor) for a parallel tuned circuit is [21]:

$$
Q=\frac{B}{G} .
$$

For the researches of the electrical properties depending on temperature is used the oven Memmert UNE 400. The electrical parameters are determined in the range from 20 to $130^{\circ} \mathrm{C}$; as a result are used average values obtained from the heating and the cooling processes.

\section{RESULTS AND DISCUSSION}

The compression curves of the solid, monolith sapropel from the lake Ubogova are given in Fig.1. 
Hereof we see that the solid, monolith sapropel is a breakable material, during the elastic deformation compression (straight phases, where the Hooke's law is valid) remains almost intact until the rupture. The compression curves of the pressed (with strength $312 \mathrm{MPa}$ ) sapropel-powder samples from the lake Ubogova see in Fig.2. The main mechanical properties of the solid sapropel during the compression are given in Table 1. A large scattering of the mechanical properties of the solid, monolith sapropel is related with problems during the sample preparation- in the drying process they shrinks hard, appear cracks, whose formation during the simple drying is not possible to exclude. The scattering of the mechanical properties of the solid, pressed sapropel can be explained by the fact that the granulometric

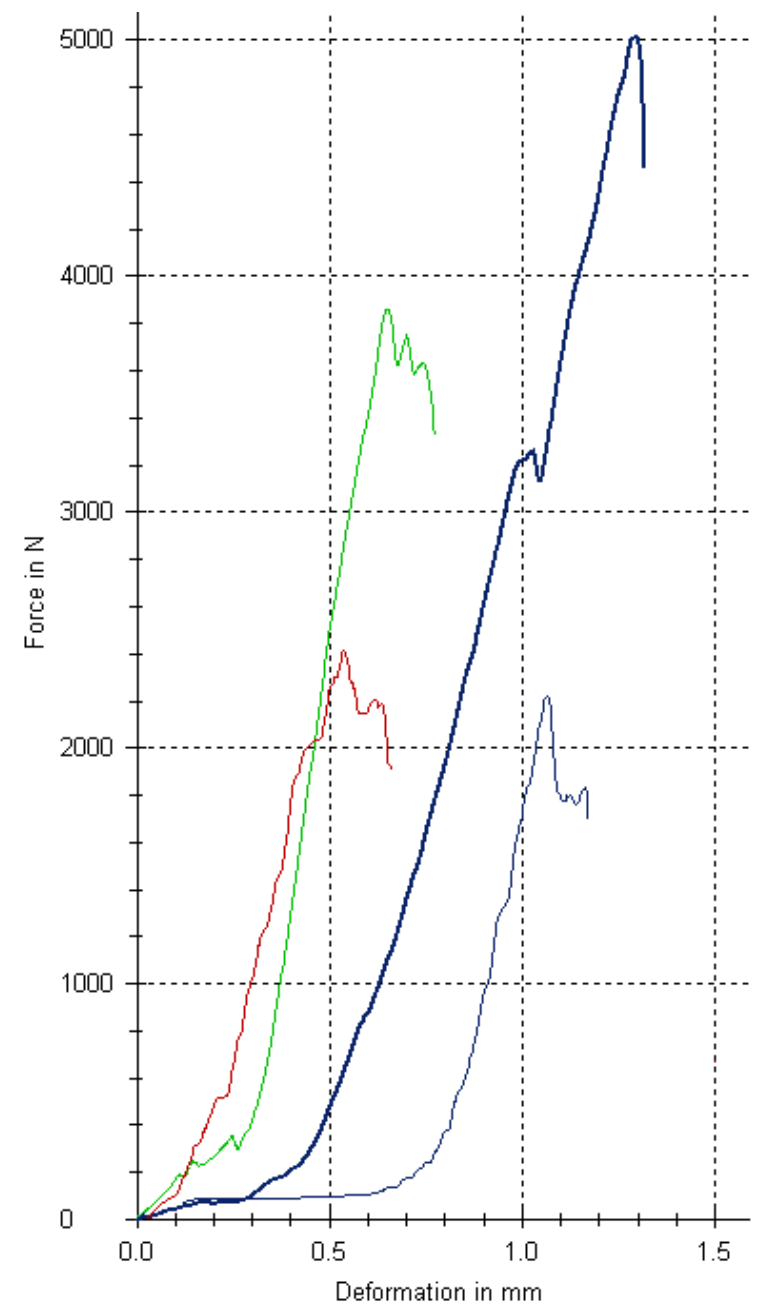

Fig.1. The compression curves of the sapropel samples (monolith cube $11 \times 11 \times 11 \mathrm{~mm}$ ) from the lake Ubogova. composition of the sample-forming powder was not constant.

The given experiments enable to compare the mechanical properties of the sapropel products, when they are obtained during the drying process and the powder pressing process. The strength of the sapropelpowder samples is more than two times lower than the strength of the samples that are obtained during the drying process. On the other hand, the pressed-powder samples have lower scattering of the mechanical properties than the samples that were dried. It means that during the powder-pressing process we can get products with the significantly more precise mechanical properties than using the method of drying.

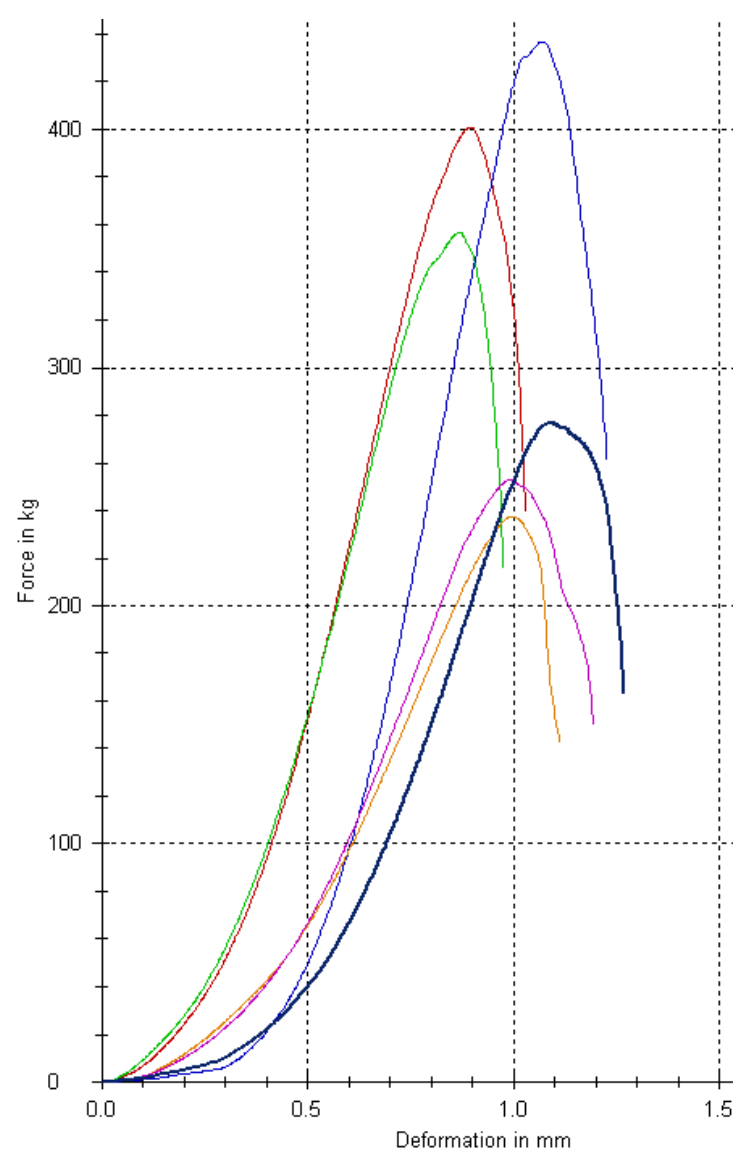

Fig.2. The compression curves of the pressed (with a strength $312 \mathrm{MPa}$ ) sapropel-powder samples (cylinders: diameter $19.3 \mathrm{~mm}$, average height $21 \mathrm{~mm}$ ) from the lake Ubogova. 
TABLE 1

MECHANICAL PROPERTIES OF THE SOLID SAPROPEL FROM THE LAKE UBOGOVA AT $20^{\circ} \mathrm{C}$

\begin{tabular}{|l|l|l|}
\hline & $\begin{array}{l}\text { Solid, monolith } \\
\text { sapropel }\end{array}$ & $\begin{array}{l}\text { Pressed (312MPa) } \\
\text { sapropel-powder }\end{array}$ \\
\hline $\begin{array}{l}\text { Ultimate } \\
\text { compressive } \\
\text { strength, MPa }\end{array}$ & $28 \pm 15$ & $11.3 \pm 2.8$ \\
\hline Ultimate strain, \% & $4.0 \pm 2.6$ & $3.51 \pm 0.39$ \\
\hline $\begin{array}{l}\text { Young's modulus, } \\
\text { MPa }\end{array}$ & $760 \pm 320$ & $430 \pm 120$ \\
\hline Hardness & $<25 \mathrm{HRB}$ & 20 Shore C \\
\hline Density, $\mathrm{kg} / \mathrm{m}^{3}$ & $1260 \pm 80$ & - \\
\hline
\end{tabular}

One of the methods used by making products from metal powder is following: at first products are formed under compressive load, after it heated $30-90 \mathrm{~min}$ at $0.6-0.9$ from the powder melting temperature, as a result there are forming stronger bonds between the powder particles, consequently increases the strength [22]. A similar approach is used also in the sapropel powder (although it is not a metal) case: the powder from the solid sapropel is to pour into cylindrical mould and to press applying the mechanical stress $\sigma$; is gotten a cylindrical sapropel sample; this sample is to take out from the mould, to put into the oven and to heat 1 hour at $150^{\circ} \mathrm{C}$ (temperature is chosen following in order to avoid an ignition of the sapropel); after the cooling in air, the sample is to subject to the compression test. The ultimate compressive strength of the pressed sapropel-powder samples from the lake Ubogova with and without the heat treatment depending on the pressing strength $\sigma$, applied during the formation, is given in Fig.3, the ultimate strain $\varepsilon_{\max }$ depending on $\sigma$ see in Fig.4. From these figures, we see that the heat treatment after the formation worsens the mechanical properties of the sapropel products (if the sapropel powder is without admixtures).

The next researches in this area could be related to obtaining the relationships between the granulometric composition, pressure force, concentration of various admixtures (e.g. surfactants, low melting substances etc.), temperature and time during the formation and the heating processes and also for the mechanical properties of the sample- ultimate strength, ultimate strain, hardness. It would enable to improve the mechanical properties of the samples that are gotten using the powder pressing method. These researches would give a chance to create products from the solid sapropel, using the powder pressing method that is significantly simpler than the formation by the drying.

To research the electrical properties of the solid sapropel are used six different samples: 1, 2, 3 monolith (obtained drying the sapropel) sapropel from the lake Ubogova, 4 - pressed (with a strength $250 \mathrm{MPa}$ ) sapropel-powder from the lake Ubogova, 5 pressed (with a strength $250 \mathrm{MPa}$ ) sapropel-powder from the Diunokḷ bay, 6 - monolith sapropel from the Diunokḷ bay.

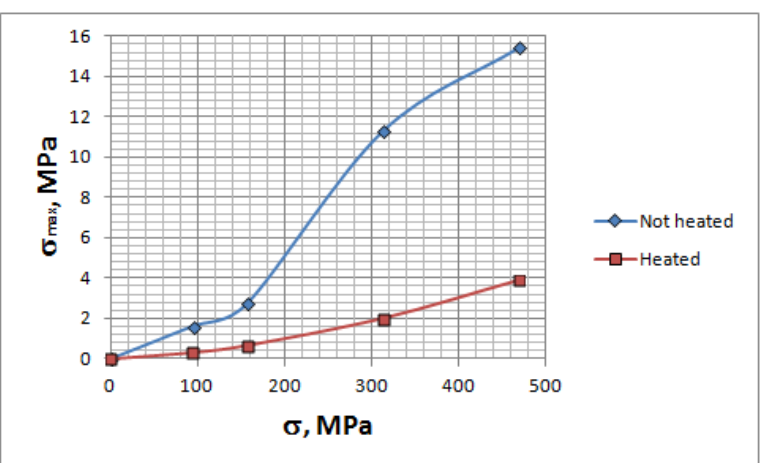

Fig.3. The ultimate compressive strength omax of the sapropel samples (cold-pressed sapropel powder) from the lake Ubogova depending on the pressing strength $\sigma$ during the preparation of the samples; rhombus corresponds to the samples, which are not subjected to the heat treatment, squares- to samples that after the pressing were heated 1 hour at $150^{\circ} \mathrm{C}$; measurement error of $\sigma \mathrm{max}$ is $8.8 \%$.

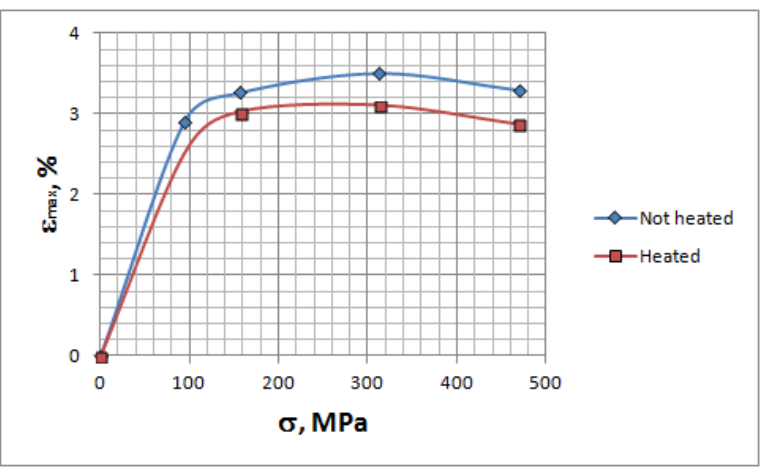

Fig.4. The ultimate strain $\varepsilon$ max of the sapropel samples (coldpressed sapropel powder) from the lake Ubogova depending on the pressing strength $\sigma$ during the preparation of the samples; rhombus corresponds to the samples, which are not subjected to the heat treatment, squares- to the samples that after the pressing were heated 1 hour at $150^{\circ} \mathrm{C}$; measurement error of emax is $11 \%$.

The electrical properties of the solid sapropel in the DC case at $20^{\circ} \mathrm{C}$ are given in Tab.2. As in the semiconductors $\rho=10^{-4} \ldots 10^{7} \Omega \cdot \mathrm{m}[23]$, it means that the solid sapropel is an isolator (dielectric).

TABLE 2

ELECTRICAL PROPERTIES OF THE SOLID SAPROPEL IN THE DC CASE AT THE TEMPERATURE $\mathrm{T}=20^{\circ} \mathrm{C}$

\begin{tabular}{|c|c|c|}
\hline & Lake Ubogova & Diunokḷa bay \\
\hline \multicolumn{3}{|c|}{ Solid, monolith sapropel } \\
\hline $\begin{array}{l}\text { Specific electrical } \\
\text { resistance, } \Omega \cdot \mathrm{m}\end{array}$ & $(4.3 \pm 2.1) \cdot 10^{8}$ & $(4.0 \pm 3.2) \cdot 10^{9}$ \\
\hline Relative permittivity & $7.4 \pm 3.0$ & $16.6 \pm 3.0$ \\
\hline \multicolumn{3}{|c|}{ Pressed (with a strength $250 \mathrm{MPa}$ ) sapropel-powder } \\
\hline $\begin{array}{l}\text { Specific electrical } \\
\text { resistance, } \Omega \cdot \mathrm{m}\end{array}$ & $(6.9 \pm 4.8) \cdot 10^{8}$ & $(4.9 \pm 3.3) \cdot 10^{8}$ \\
\hline Relative permittivity & $9.3 \pm 3.0$ & $7.7 \pm 3.0$ \\
\hline
\end{tabular}


The frequency curves of the solid sapropel for the specific electrical resistance are given in Fig.5, for the relative permittivity - in Fig.6, for the quality factor in Fig.7. From the Fig.5 we see the general tendency if the frequency $\mathrm{f}$ increases, the specific electrical resistance $\rho$ decreases. In a dielectric exists not only an electron conduction mechanism (the current is transferred by the free electrons, the number of which is small in the dielectric) but also a polarization conduction mechanism: the electrons that are closely related to the crystal lattice cannot move from one atom to another but within the limits of the atom can shift in the direction of the electric field and polarize the atom [24]; when the frequency increases, the flow of these polarization-electrons becomes more intense in the direction of the electric field, the polarizationcurrent becomes higher but the resistance - lower. An another explanation of this phenomenon could be the fact that in the case of the low frequencies the oxidation-reduction reactions have a high intensity, consequently decreases the concentration of the charged particles (dipoles, ions, electrons) near the electrodes that increases the resistance [25].

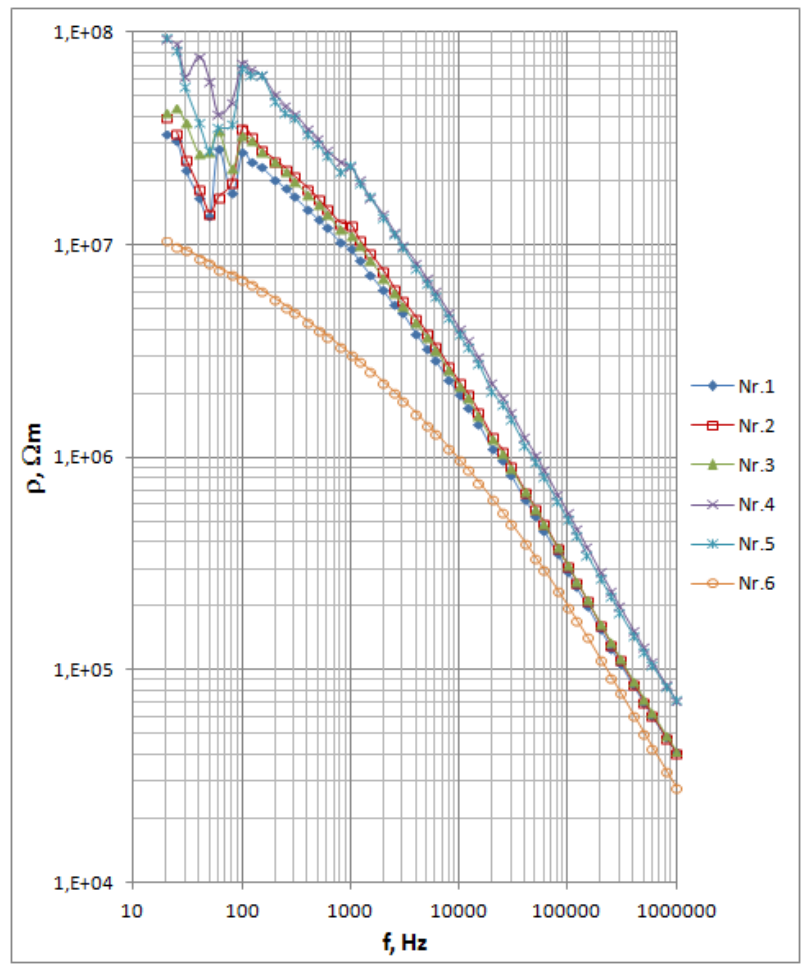

Fig.5. The specific electrical resistance of the solid sapropel depending on the frequency at $20^{\circ} \mathrm{C}$
At the frequency $50 \mathrm{~Hz}$, the samples 1-5 have a local minimum of the specific electrical resistance, after which, in the frequency interval $50-100 \mathrm{~Hz}$, follows the 1.5-2.4-time increase of the specific electrical resistance. This could be explained that in the frequencies near $50 \mathrm{~Hz}$ is observed a maximum of the resonance at some large, electrically charged molecular formations. From the Fig. 5 is obvious that in the frequency range $20-100 \mathrm{~Hz}$ the specific electrical resistance of the samples $1-5$ is especially sensitive on the frequency.

From the relative permittivity $\varepsilon$ - frequency curve (see Fig.6) can be seen, if the frequency of the electric field increases, the relative permittivity decreases. An explanation is the decrease in a degree of the polarization of the ions and the dipoles, while the electric field frequency increases; at higher frequencies, the change of the position of the ions and the dipoles according to the electric field direction delays [Pavlov]. In addition, the relative permittivity has a local minimum in the frequency range 20$100 \mathrm{~Hz}$, where $\varepsilon$ is especially sensitive on the frequency.

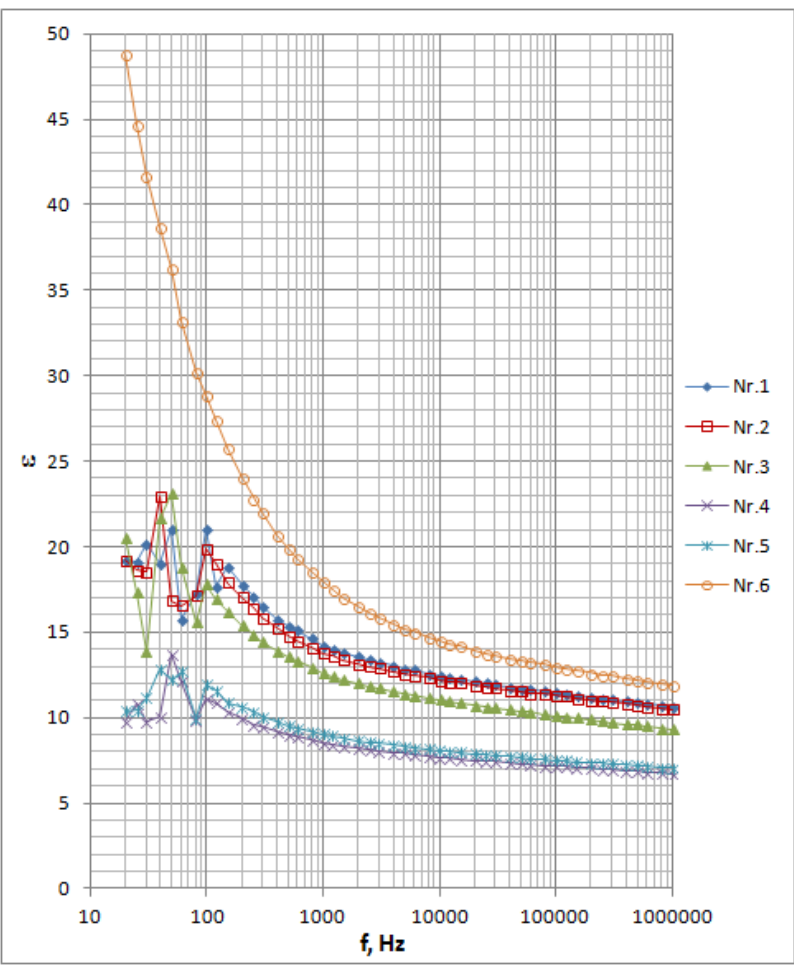

Fig.6. The relative permittivity of the solid sapropel depending on the frequency at $20^{\circ} \mathrm{C}$ 


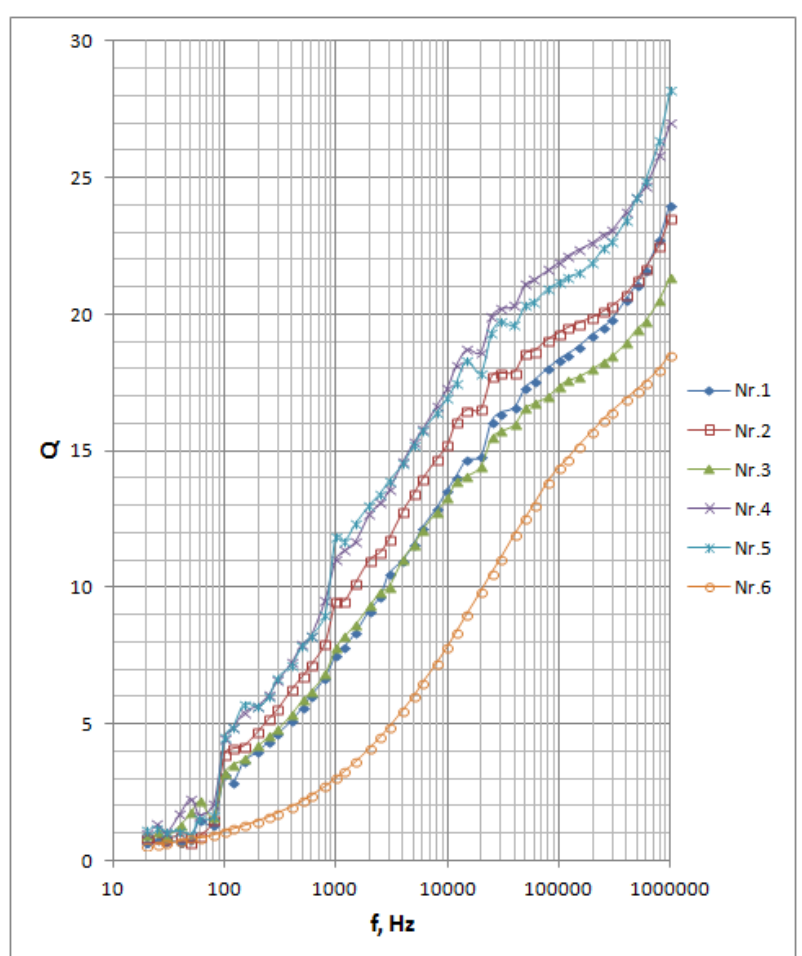

Fig.7. The quality factor of the solid sapropel depending on the frequency at $20^{\circ} \mathrm{C}$

If the relationships $\rho=\rho(f)$ and $\varepsilon=\varepsilon(f)$ are known, then the solid sapropel can be used in sensors to determine the frequency of the electric field. By measuring the electrical resistance or capacity of the sensor can be determined the frequency of the electrical field. Best of all is to use it in the frequency range, in which $\rho$ and $\varepsilon$ are especially dependent on $\mathrm{f}$; in this case - in the range $20-100 \mathrm{~Hz}$.

From the Fig.7 can be seen, if the frequency grows, the quality factor $\mathrm{Q}$ increases from $0.57-1.09$ at the frequency $20 \mathrm{~Hz}$ to $18-28$ at the frequency $1 \mathrm{MHz}$; the quality factor of the pressed-sapropel samples $(4,5)$ is higher; the local minimum of the quality factor is observed at frequencies $50-100 \mathrm{~Hz}$ that can be explained by the significant decrease of the electrical resistance in this frequency range. From the relationships (1)- (5) we get:

$$
Q=2 \pi \varepsilon_{0} f \rho \varepsilon
$$

If the growth of $\mathrm{f}$ is faster than the reduction of $\rho \cdot \varepsilon$, where $\rho=\rho(f)$ and $\varepsilon=\varepsilon(f)$, then, at the increasing frequency $f$, the quality factor $\mathrm{Q}$ must grow. It means that in the future materials from the solid sapropel could be used in electrical circuits (e.g. in condensers) with high $(>1 \mathrm{MHz})$ frequencies.

Is found that the relative permittivity of the solid sapropel during the increase of the temperature from 20 to $130^{\circ} \mathrm{C}$ grows (see Fig.8). The samples of the solid, monolith sapropel $(1,2,3$ and 6) have an increase of 11-16 times; the samples from the pressed powder (4 and 5) - 1.7-3.8 times. An explanation is the existence of air pores in the samples from the pressed powder. In this research is found out that a change of the total capacity $\mathrm{C}_{0}$ (see relationship (1)) of sample-holder electrodes (air condenser) and supplywires depending on the temperature is several times lower than a change of the capacity $\mathrm{C}$ of the sapropel condenser with the same dimension.

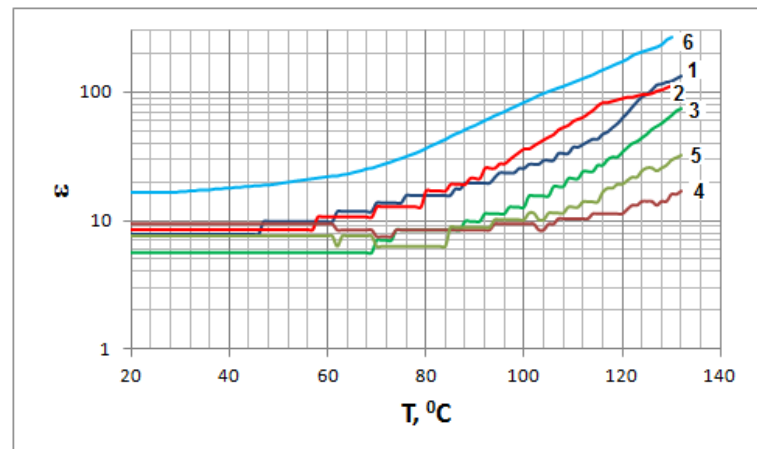

Fig.8. The relative permittivity of the solid sapropel (in the DC case) depending on the temperature; before that samples were not subjected to the heat treatment at the elevated temperature; measurement error $\Delta \varepsilon=3$

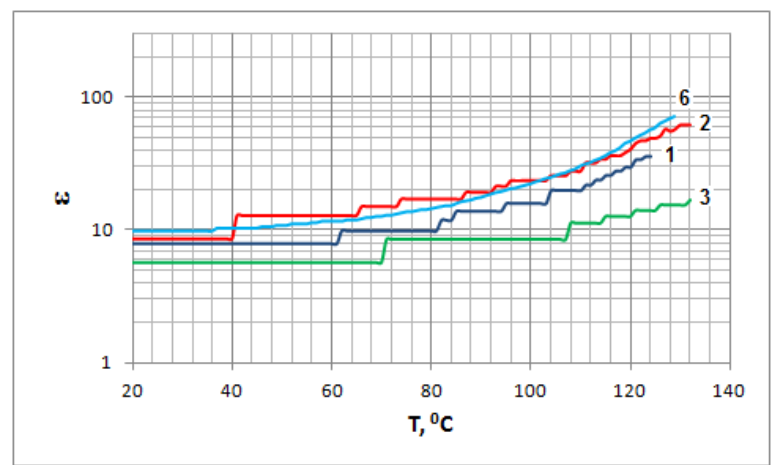

Fig.9. The relative permittivity of the solid sapropel (in the DC case) depending on the temperature; before that samples were subjected to the heat treatment- heated to $140^{\circ} \mathrm{C}$ and cooled in the oven to $20^{\circ} \mathrm{C}$; measurement error $\Delta \varepsilon=3$

Measurements of the relative permittivity depending on the temperature were repeated for the same samples (see Fig.9). Is determined that the growth of the relative permittivity of the samples, which has been heated before, depending on the temperature is decreased. An explanation could be related with two factors: 1) with the accelerated diffusion processes and the formation of stronger chemical bonds during the initial heating that complicates the polarization of the sapropel; 2) with the evaporation of the moisture and the volatile substances. This effect could be used in electronic and mechanical devices producing indicators (sapropel condensers) with a memory: if the device has been heated during the exploitation time, then the capacity of the condenser will be decreased; the value of the capacity could store the information about the heatingtemperature and the heating-time. For this purpose we 
must know the relationships between the capacity, heating-temperature and heating-time of each type of the indicators; the indicator must be located in a hermetic casing so that the effect of the air humidity would be excluded.

\section{CONCLUSION}

The solid, monolith sapropel has the ultimate compressive strength $28 \pm 15 \mathrm{MPa}$, ultimate strain $4.0 \pm 2.6 \%$, Young's modulus $760 \pm 320 \mathrm{MPa}$, hardness $\mathrm{HRB}<25$, density $1260 \pm 30 \mathrm{~kg} / \mathrm{m}^{3}$, specific electrical resistance $2.2 \cdot 10^{8} \Omega \cdot \mathrm{m}-7.2 \cdot 10^{9} \Omega \cdot \mathrm{m}$, static relative permittivity $4.4-19.6$.

If the electric field frequency $f$ in the range from $20 \mathrm{~Hz}$ to $1 \mathrm{MHz}$ increases, then the specific electrical resistance $\rho$ and the relative permittivity $\varepsilon$ decrease but the quality factor $Q$ grows. If the relationships $\rho=\rho(f)$ and $\varepsilon=\varepsilon(f)$ are known, then the solid sapropel can be used in the sensors to determine the electric field frequency, basing on the measurements of the electrical resistance or the capacity of the sensor.

If the temperature increases from 20 to $130^{\circ} \mathrm{C}$, then the relative permittivity of the solid, monolith sapropel grows 11-16 times, of the pressed sapropel powder1.7-3.8 times. If the solid sapropel is subjected to the heat treatment before the measurements (heated till $130^{\circ} \mathrm{C}$ and cooled till $20^{\circ} \mathrm{C}$ in the oven), then, after the repeated heating, its relative permittivity decreases: 0 1.7 times at $20^{\circ} \mathrm{C}$ and $1.8-4.2$ times at $130^{\circ} \mathrm{C}$. This effect could be used in indicators (sapropel condensers) with a memory; their capacity would store the information about emergency cases of the device during the exploitation time - heatingtemperature and heating-time.

Forming of solid monolithic sapropel workpieces is problematic; technologically simpler is forming of workpieces under pressure out of sapropel powder. If cold pressing load for sapropel powder is $312 \mathrm{MPa}$, then ultimate compressive strength is $11.3 \pm 2.8 \mathrm{MPa}$ that is more than 2 times lower than for monolithic sapropel. Heating of cold formed by pressing sapropel powder workpieces is not permitted (if powder is not modified, there are no surface active substances or admixtures in that), because of considerable decrease of strength. Further research can be concerned with modifying of sapropel powder particles, finding of surface active substances and admixtures, that increase strength of formed by pressure workpieces.

\section{ACKNOWLEDGMENTS}

This work has been supported by Rēzeknes Augstskola and Jade University of Applied Sciences.

\section{REFERENCES}

[1] Nikolaeva L. A., Latyshev V. G., Burenina O. N. Fuel Briquettes from Brown Coals of Yakutia. ISSN 0361-5219, Solid Fuel Chemistry, 2009, Vol. 43, No. 2, pp. 109-112.
[2] Rohling E.J. (1994) Review and new aspects concerning the formation of eastern Mediterranean sapropels. Mar. Geol. 122, 1628.

[3] Rossignol-Strick M., Nesterhoff W., Olive P., and Vergnaud-Grazzini C. After the deluge: Mediterranean stagnation and sapropel formation. Nature 295, 1982, p. 105110 .

[4] Hilde F. Passier. Sulphur geochemistry and sapropel formation Syngenetic and diagenetic signals in eastern Mediterranean sediments. Mededelingen van de Faculteit Aardwetenschappen, Universiteit Utrecht, ISBN 90-5744-0164, 1998, pp.154.

[5] Stankevica K., Kḷavins M. Sapropelis un tā izmantošanas iespējas (Sapropel and Its Application Possibilities)// Material Science and Applied Chemistry. 2013 / 29, p.109-126. (in Latvian)

[6] Dement'ev V. A. Removal of organic sediments from reservoirs and lakes and their processing// Power Technology and Engineering; Vol. 44, No. 4, 2010, p.289-292.

[7] Pleiksnis, S., Teirumnieka E. Concrete containing sapropel and hemp sheaves for insulation of buildings. Latvijas Republikas patents: Nr. 14869, 20.11.2014. C04B18/18, C04B18/24, 20.06.2014.

[8] Черский И. Н., Давыдова Н. Н. Проблемы рационального использования сапропелевых ресурсов// Вестник Северо-Восточного научного центра ДВО РАН. 2009. - № 4. - C. 88-92. (in Russian)

[9] Kireicheva, L.V., Khokhlova, O.B. Sapropeli: sostav, svoistva, primenenie (Sapropels: Composition, Properties, and Use)), Moscow: Roma, 1998. (in Russian)

[10] Ядрихинский В. Ф., Перк А. А., Егорова М. С. Применение препарата из сапропеля для лечения демодекоза собак// Актуальные вопросы ветеринарной медицины. - Новосибирск, 2003. - С. 71-72. (in Russian)

[11] Павлова П. А., Перк А. А., Егорова М. С. Влияние биостимулятора из сапропеля на рост и развитие интродуцентов в условиях многолетней мерзлоты [Якутия]// Фундаментальные и прикладные проблемы ботаники в начале XXI века: материалы Всерос. конф. (Петрозаводск, 22-27 сент. 2008 г.). - Петрозаводск, 2008. Ч. 6: Экологическая физиология и биохимия растений. Интродукция растений. - C. 291-294. (in Russian)

[12] Перк А. А. Использование сапропелей криолитозоны в качестве источника получения биологически активных веществ гуминового ряда// Перспективы фитобиотехнологии для улучшения качества жизни на Севере: материалы Междунар. конф. с элементами научной школы для молодежи, г. Якутск, Россия, 11-16 окт. 2010 г.- Якутск, 2010. - C. 154-158. (in Russian)

[13] Rinna J., Warning B., Meyers P. A., Brumsack H.-J., Rullkötter J. Combined organic and inorganic geochemical reconstruction of paleodepositional conditions of a Pliocene sapropel from the eastern Mediterranean Sea. Geochimica et Cosmochimica Acta, Vol. 66, No. 11, pp. 1969-1986, 2002.

[14] Edouard Bard, Gilles Delaygue, Frauke Rostek, Fabrizio Antonioli, Sergio Silenzi, Daniel P. Schrag. Hydrological conditions over the western Mediterranean basin during the deposition of the cold Sapropel 6 (ca. $175 \mathrm{kyr}$ BP). Earth and Planetary Science Letters 202 (2002) 481-494.

[15] Thomson J., Higgs N.C., Wilson T.R.S., Croudace I.W., de Lange G.J., and van Santvoort P.J.M. (1995) Redistribution and geochemical behaviour of redox-sensitive elements around S1, the most recent eastern Mediterranean sapropel. Geochim. Cosmochim. Acta 59, 3487-3501.

[16] Angelidis M.O., Radakovitch O., Veron A., Aloupi M., Heussner S., Price B. Anthropogenic metal contamination and sapropel imprints in deep Mediterranean sediments. Marine Pollution Bulletin 62 (2011) 1041-1052.

[17] Van Santvoort P.J.M., de Lange G.J., Thomson J., Cussen H., Wilson T.R.S., Krom M.D., Ströhle K. (1996) Active post-depositional oxidation of the most recent sapropel (S1) in sediments of the eastern Mediterranean. Geochim. Cosmochim. Acta 60, 4007-4024. 
[18] Галкина, И. С. Сапропель Оренбургской области: биологическая активность и пути применения. Диссертации кандидата химических наук. (Galkina I.S Sapropel Orenburg region: biological activity and ways of application; Dissertation of the candidate of chemical sciences) ВАК 05.17.07, Тула, 2003, c.221. (in Russian).

[19] Juan C. Larrasoana, Andrew P. Roberts, Joseph S. Stoner, Carl Richter, Rolf Wehausen. A new proxy for bottomwater ventilation in the eastern Mediterranean based on diagenetically controlled magnetic properties of sapropelbearing sediments. Palaeogeography, Palaeoclimatology, Palaeoecology 190, 2003, p.221-242.

[20] Petrunin G. I., Popov V. G., Soskov A. V. Thermal Properties of the Bottom Sediments of the Black Sea// Moscow University Physics Bulletin, 2008, Vol. 63, No. 1, pp. $61-66$.
[21] HP 4284A Precision LCR meter. Operation manual. Hewlett Packard, 1998

[22] Дальский А.М. [и др.] Технология конструкционных материалов : учеб. для студентов машиностроит. Вузов, 6е изд, Москва: Машиностроение, 2005. - 592 с. (in Russian)

[23] Siegfried Hunklinger: Festkörperphysik. Oldenbourg Verlag, 2009, ISBN 978-3-486-59045-6, S. 378. (in Germany)

[24] Павлов П.В., Хохлов А.Ф. Физика твердого тела// Москва: Высшая школа, 2000. (in Russian)

[25] Старцев А.Э., Ягубов 3.X. Влияние удельной электропроводности бурового раствора на энергетические характеристики электромагнитного канала связи забойной телесистемы. Электронный научный журнал «Нефтегазовое дело», 2011, № 3 (in Russian). 